\title{
Promotion of oxygen reduction and evolution by applying a nanoengineered hybrid catalyst on cobalt free electrodes for solid oxide cells
}

Tong, Xiaofeng; Xu, Yu; Tripkovi, orije; Hendriksen, Peter Vang; Kiebach, Wolff Ragnar; Chen, Ming

Published in:

Journal of Materials Chemistry A

Link to article, DOI:

$10.1039 / \mathrm{d} 0 \mathrm{ta0} 2979 \mathrm{c}$

Publication date:

2020

Document Version

Peer reviewed version

Link back to DTU Orbit

Citation $(A P A)$ :

Tong, X., Xu, Y., Tripkovi, ., Hendriksen, P. V., Kiebach, W. R., \& Chen, M. (2020). Promotion of oxygen reduction and evolution by applying a nanoengineered hybrid catalyst on cobalt free electrodes for solid oxide cells. Journal of Materials Chemistry A, 8(18), 9039-9048. https://doi.org/10.1039/d0ta02979c

\section{General rights}

Copyright and moral rights for the publications made accessible in the public portal are retained by the authors and/or other copyright owners and it is a condition of accessing publications that users recognise and abide by the legal requirements associated with these rights.

- Users may download and print one copy of any publication from the public portal for the purpose of private study or research.

- You may not further distribute the material or use it for any profit-making activity or commercial gain

- You may freely distribute the URL identifying the publication in the public portal 


\title{
Promotion of oxygen reduction and evolution by applying a nanoengineered hybrid catalyst on cobalt free electrodes for solid oxide cells
}

\author{
Xiaofeng Tong ${ }^{\mathrm{a}}, \mathrm{Yu} \mathrm{Xu}^{\mathrm{a}}$, Dordije Tripkovic ${ }^{\mathrm{a}}$, Peter Vang Hendriksen ${ }^{\mathrm{a}}$, Wolff-Ragnar Kiebach ${ }^{\mathrm{a}}$, and \\ Ming Chen ${ }^{\mathrm{a*}}$
}

\begin{abstract}
A key requirement for the widespread commercialization of solid oxide cell (SOC) technology is to develop cost-effective oxygen electrodes with sufficiently high electro-catalytic activity and durability at intermediate temperatures $\left(600-750^{\circ} \mathrm{C}\right)$. Here we report a remarkable enhancement of electro-catalytic activity of cobalt-free ( $\left.\mathrm{La}_{0.6} \mathrm{Sr}_{0.4}\right)_{0.98} \mathrm{FeO}_{3-\delta}$ (LSF) electrodes by applying a nanoengineered hybrid catalyst coating composed of nanoparticles of $\mathrm{Ce}_{0.85} \mathrm{Gd}_{0.15} \mathrm{O}_{2-\delta}$ (CGO) and $\mathrm{Pr}_{6} \mathrm{O}_{11}$ via coinfiltration. Different from the conventional infiltration with a precursor of metal nitrate, here a mixture solution of colloidal CGO nanocrystals and $\operatorname{Pr}\left(\mathrm{NO}_{3}\right)_{3}$ is used for infiltration to enable the desired nanoengineered architecture. The resulting hybrid-catalyst-coated LSF electrode exhibits a very low polarization resistance of $0.017 \Omega \mathrm{cm}^{2}$ at $750{ }^{\circ} \mathrm{C}$, about one order of magnitude lower than that of bare LSF $\left(0.197 \Omega \mathrm{cm}^{2}\right)$. Furthermore, the Ni/yttria-stabilized zirconia (YSZ) fuel-electrodesupported cell with this hybrid-catalyst-coated LSF electrode displays excellent performance in both fuel-cell and electrolysis operations, while it also offers good durability tracked over $1000 \mathrm{~h}$ of fuel-cell operation. The unique catalytic activity of the hybrid-catalyst-coated LSF electrode is attributed to the combined effects of accelerating oxygen surface exchange kinetics by $\mathrm{Pr}_{6} \mathrm{O}_{11}$ and enhancing the available surface area by the nanoporous architecture of the catalyst coating. Moreover, combining with the modification of the $\mathrm{Ni} / \mathrm{YSZ}$ electrode, stable electrolysis operation at $650{ }^{\circ} \mathrm{C}$ under $-0.5 \mathrm{~A} \mathrm{~cm}-2$ with a voltage close to $1.3 \mathrm{~V}$ is achieved on a cell prepared without cobalt. This work not only opens the opportunity for applying cobalt-free oxygen electrodes in SOCs but also proposes a co-infiltration strategy to develop highly active and robust catalyst coating by combined tunning of composition and morphology, which may also be applicable to other devices such as metalair batteries and membrane reactors.
\end{abstract}

\section{Introduction}

Owing to the rapid growth in electricity generation from intermittent renewable solar and wind sources, grid-scale and long-term (e.g., seasonal) energy storage is needed to balance the supply-demand mismatch. ${ }^{1,2}$ As a promising technology to address this energy storage challenge, solid oxide cells (SOCs) have received increasing attention in recent years. ${ }^{3-6}$ They can be operated either in electrolysis mode (as solid oxide electrolysis cells, SOECs) to convert $\mathrm{H}_{2} \mathrm{O}$ and/or $\mathrm{CO}_{2}$ into $\mathrm{H}_{2}$ and/or CO using excess renewable electricity, or in fuel-cell mode (as solid oxide fuel cells, SOFC) to generate electricity on demand using the fuels produced. 5,7

Reducing the operating temperature to the intermediate temperature range $\left(600-750{ }^{\circ} \mathrm{C}\right)$ will be highly beneficial for widespread commercialization of the SOC technology. One of the technical challenges for operating SOCs in this temperature range is to ensure sufficiently high electro-catalytic activity for the oxygen reduction reaction (ORR, when operated in fuel-cell mode) and the oxygen evolution reaction (OER, when operated in electrolysis mode) as well as good durability. During the past decades, substantial efforts have been made, leading to a shift in oxygen electrode materials from the conventional electronic conducting $\mathrm{La}_{1-x} \mathrm{Sr}_{x} \mathrm{MnO}_{3}$ (LSM) compound to mixed ionicelectronic conductors (MIECs). In particular, many cobalt containing perovskite - type oxides, such as $\mathrm{La}_{0.6} \mathrm{Sr}_{0.4} \mathrm{Co}_{0.2} \mathrm{Fe}_{0.8} \mathrm{O}_{3-\delta} \quad(\mathrm{LSCF})^{8,} \quad{ }^{9}, \quad \mathrm{La}_{0.6} \mathrm{Sr}_{0.4} \mathrm{CoO}_{3-\delta} \quad(\mathrm{LSC})^{10}$, $\mathrm{Ba}_{0.5} \mathrm{Sr}_{0.5} \mathrm{Co}_{0.8} \mathrm{Fe}_{0.2} \mathrm{O}_{3-\delta}$ (BSCF) ${ }^{11,12}, \mathrm{Sm}_{0.5} \mathrm{Sr}_{0.5} \mathrm{CoO}_{3-\delta}(\mathrm{SSC})^{13}$, and $\mathrm{PrBa}_{0.8} \mathrm{Ca}_{0.2} \mathrm{CO}_{2} \mathrm{O}_{5+\delta}(\mathrm{PBCC})^{14}$ have been developed, and have shown to provide favorable catalytic activity at intermediate temperatures. Nevertheless, these cobalt - containing materials are not without problems. The materials show a large thermal expansion mismatch with commonly used electrolyte materials, i.e., yttria-stabilized zirconia (YSZ) and scandiastabilized zirconia (SSZ). Their chemical stability is limited, which together with the volatilization and diffusion of cobalt during high-temperature sintering cause various cell fabrication issues. ${ }^{15-17}$ Furthermore, cobalt is price volatile and it may become resource-limited due to the rocketing demand of cobalt oxide for lithium-ion batteries. ${ }^{16}$ Finally, it is considered carcinogenic. All these factors push the development of cobaltfree electrodes for SOCs.

$\mathrm{LaFeO}_{3}$-based oxides are attractive alternatives because of their similar thermal expansion coefficients to that of the conventional electrolyte materials and improved chemical stability. Fe is highly abundant and low cost. ${ }^{18,} 19$ However, $\mathrm{LaFeO}_{3}$-based materials exhibit relatively low catalytic activity for ORR and OER in comparison with cobalt-containing materials. For example, $\mathrm{La}_{0.5} \mathrm{Sr}_{0.5} \mathrm{FeO}_{3-\delta}$ electrode was reported to show a polarization resistance $\left(R_{p}\right)$ of $0.79 \Omega \mathrm{cm}^{2}$ at $700{ }^{\circ} \mathrm{C}^{20}$, more than 2 times that of the most commonly used LSCF electrode $\left(0.34 \Omega \mathrm{cm}^{2}\right)^{9}$ and even $\sim 11$ times that of more cobalt-rich composite like PBCC electrodes $\left(0.071 \Omega \mathrm{cm}^{2}\right)^{14}$ under the same conditions. Recently, surface modification via infiltration of oxygen electrodes with catalytically-active nanoparticles/coating has emerged as an effective approach to enhance the activity. ${ }^{14,}$ 21-23 Those nanoparticles/coatings are generally introduced by infiltration of nitrate solutions that subsequently decomposed via heat treatment. By this approach the overall composition of the coating is well controlled but the 
phase and the morphology of coating, which is also important for performance, is not well controlled.

Here, we report on $\left(\mathrm{La}_{0.6} \mathrm{Sr}_{0.4}\right)_{0.98} \mathrm{FeO}_{3-\delta}$ (LSF)-based electrodes that can be strongly improved to a level allowing operation at $\geq$ $650{ }^{\circ} \mathrm{C}$ by applying a nanoengineered hybrid catalyst coating realized through a nonconventional infiltration route. The hybrid coating is composed of a nanoporous layer of nanoparticles of $\mathrm{Ce}_{0.85} \mathrm{Gd}_{0.15} \mathrm{O}_{2-\delta}$ (CGO) and $\mathrm{Pr}_{6} \mathrm{O}_{11}$. The coating is achieved by infiltrating the porous LSF backbone with a solution of colloidal CGO nanocrystals and $\operatorname{Pr}\left(\mathrm{NO}_{3}\right)_{3}$. $\operatorname{Pr}$-oxide was included because of its good catalytic activity towards the ORR. ${ }^{21}, 24,25$ The resulting hybrid-catalyst coated LSF electrode displayed a very low $R_{p}$ of $0.017 \Omega \mathrm{cm}^{2}$ at $750{ }^{\circ} \mathrm{C}$. This performance is superior to those of the cobalt-containing electrodes mentioned previously. The effect of coating on oxygen surface exchange kinetics was investigated by examining the distribution of relaxation time (DRT) of the impedance spectra and electrical conductivity relaxation (ECR) measurements. Moreover, the hybrid-catalyst-coated LSF electrode demonstrated excellent performance and durability in full cells for both practical fuel-cell and electrolysis operations.

\section{Experimental}

\subsection{Synthesis and characterization of CGO nanocrystals}

The CGO nanocrystals used in this work were synthesized by a continuous hydrothermal flow synthesis (CHFS) method. The process details can be found elsewhere. ${ }^{26}$ Shortly, in an inhouse developed CHFS flow-type reactor, a precursor stream of $\mathrm{Ce}\left(\mathrm{NO}_{3}\right)_{3}(0.04 \mathrm{~mol} \mathrm{~L}-1)$ and $\mathrm{Gd}\left(\mathrm{NO}_{3}\right)_{3}\left(0.01 \mathrm{~mol} \mathrm{~L}^{-1}\right)$ was mixed with a stream of supercritical water $\left(396{ }^{\circ} \mathrm{C}, 26 \mathrm{MPa}\right)$. The nanocrystals nucleated and grew upon mixing. The nanocrystals were collected in the outflow that was cooled down and depressurized to atmospheric pressure. The nanocrystals were then separated from the suspension by using a centrifuge, washed in deionized water and ethanol, and dried for later processes. Bright field TEM (BF-TEM) and high-resolution TEM (HR-TEM) images were taken on a JEOL 3000F field emission transmission electron microscope that operates at $300 \mathrm{kV}$.

\subsection{Fabrication of symmetrical cells}

Symmetrical cells with the bare LSF electrodes were prepared by printing an in-house developed LSF ink onto both sides of commercially available $\mathrm{Ce}_{0.9} \mathrm{Gd}_{0.1} \mathrm{O}_{2-\delta}$ (CGO10) electrolyte (KERAFOL). The ink was obtained by mixing LSF powders (KUSAKA, 85 wt.\%) and carbon powders (15 wt.\%) in an organic vehicle composed of solvent, dispersant, and binder. After printing and drying, the cells were sintered at $1100{ }^{\circ} \mathrm{C}$ for $5 \mathrm{~h}$ to form porous LSF electrodes (with an active area of $0.28 \mathrm{~cm}^{2}$ ). Three types of symmetrical cells with $\mathrm{CGO}, \operatorname{Pr}_{6} \mathrm{O}_{11}$, and the hybrid-catalyst $\left(\mathrm{CGO}+\mathrm{Pr}_{6} \mathrm{O}_{11}\right)$-coated LSF electrodes, respectively, were prepared by infiltrating colloidal CGO solution, $\operatorname{Pr}\left(\mathrm{NO}_{3}\right)_{3}$ solution, and a mixture solution of colloidal CGO nanocrystals and $\operatorname{Pr}\left(\mathrm{NO}_{3}\right)_{3}$, into porous LSF backbones with subsequent calcination at $350{ }^{\circ} \mathrm{C}$. Colloidal CGO was prepared by ultrasonically dispersing as-synthesized CGO nanocrystals in ethanol with polyethylene glycol (1 wt.\%) as surfactant. ${ }^{27}$
Pluronic P-123 surfactant (1.7 wt.\%) was added into the $\operatorname{Pr}\left(\mathrm{NO}_{3}\right)_{3}$ solution. The mixture solution was obtained by mixing above colloidal $\mathrm{CGO}$ and $\operatorname{Pr}\left(\mathrm{NO}_{3}\right)_{3}$ solutions in molar ratio of $1: 1.3$. The loadings of these coatings were adjusted to $\sim 9 \mathrm{wt} . \%$ relative to the porous LSF backbones after 3 or 4 infiltration cycles. The coatings were subsequently calcinated at $750{ }^{\circ} \mathrm{C}$ for $4 \mathrm{~h}$ during the cell start-up stage to achieve the desired crystalline phases. The X-ray diffraction (XRD) measurements were carried out with Bruker D8 Rigaku diffractometer using $\mathrm{Cu}$ $\mathrm{K} \alpha$ radiation as the source. The scanning range was $20-80^{\circ}$ and the step size was $0.01^{\circ}$. The microstructure of four types of electrodes was examined using a Zeiss Merlin scanning electron microscope (SEM).

\subsection{Fabrication of fuel-electrode-supported cells}

The fuel-electrode-supported half cells with a configuration NiO/YSZ support | NiO/YSZ fuel electrode | YSZ electrolyte | CGO10 barrier were produced by laminating and co-sintering tape-cast green tapes, as previously reported. ${ }^{28}$ The hybrid-catalyst-coated LSF oxygen electrode (with an area of $4 \mathrm{~cm}^{2}$ ) was then applied to the CGO barrier using the same procedures as described previously for the preparation of symmetrical cells. The modification of Ni/YSZ fuel electrode with CGO electrocatalysts was performed by a prereduction procedure followed by the infiltration of $\mathrm{Ce}_{0.8} \mathrm{Gd}_{0.2} \mathrm{O}_{2-\delta}$ (CGO20) nitrate precursor solution containing stoichiometric amounts of $\mathrm{Ce}\left(\mathrm{NO}_{3}\right)_{3}$ and $\mathrm{Gd}\left(\mathrm{NO}_{3}\right)_{3}$ (4:1 molar ratio to metal ions), as previously reported. ${ }^{29}$ The infiltration processes were repeated 7 times to get a loading of $\sim 110 \mathrm{mg}$ CGO20 per $1 \mathrm{~cm}^{3} \mathrm{Ni} / \mathrm{YSZ}$ structure ( $\mathrm{Ni} /$ YSZ fuel electrode + Ni/YSZ support).

\subsection{Electrochemical characterization}

The electrochemical performance of bare/coated LSF electrodes was assessed on symmetrical cells at $650-750{ }^{\circ} \mathrm{C}$ in air. The setup used for the symmetrical cell measurements can 

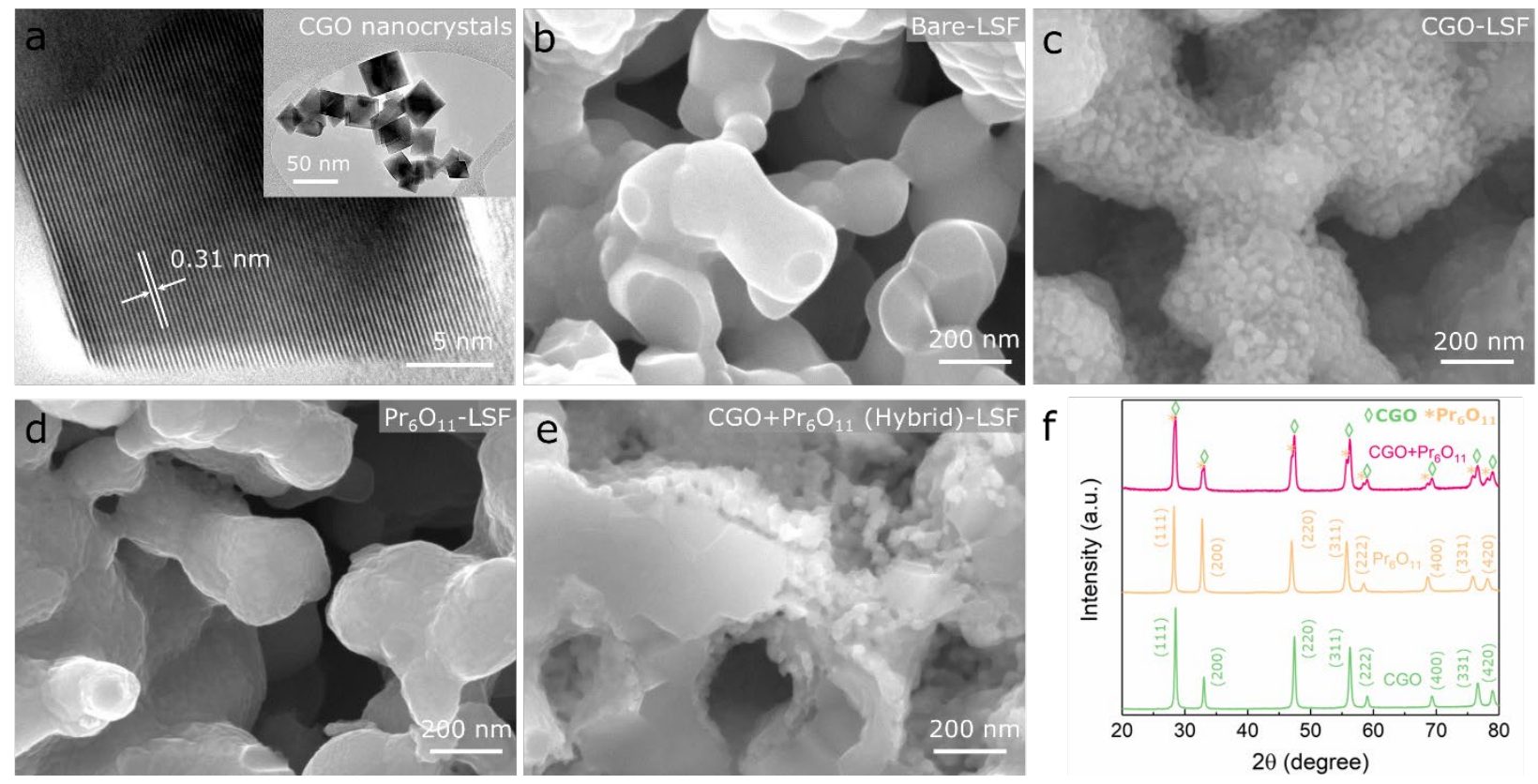

Fig. 1 (a) TEM and HRTEM images of CGO nanocrystals. Cross-sectional SEM images of four types of LSF electrodes. (b) Bare LSF, (c) CGO-coated LSF, (d) $\mathrm{Pr}_{6} \mathrm{O}_{11}$-coated LSF, and (e) hybrid-catalyst-coated LSF. (f) XRD patterns of $\mathrm{CGO}, \mathrm{Pr}_{6} \mathrm{O}_{11}$ and $\mathrm{CGO}+\mathrm{Pr}_{6} \mathrm{O}_{11}$ powders.

be found described elsewhere. ${ }^{30}$ The cells were heated to 750 ${ }^{\circ} \mathrm{C}$ with a heating rate of $1{ }^{\circ} \mathrm{C} \mathrm{min}^{-1}$ and held for $4 \mathrm{~h}$ during the start-up. The electrochemical performance and durability of the fuel-electrode-supported cells were investigated both in fuelcell and electrolysis modes using in-house constructed test rigs. ${ }^{31}$ In fuel-cell mode, the cells were tested with $4 \% \mathrm{H}_{2} \mathrm{O}$ $96 \% \mathrm{H}_{2}$ fed to the fuel electrode and dry air to the oxygen electrode. In electrolysis mode, the cells were tested with $50 \% \mathrm{H}_{2} \mathrm{O}-50 \% \mathrm{H}_{2}$ fed to the fuel electrode and dry air to the oxygen electrode. Electrochemical impedance spectroscopy (EIS) measurements were conducted using a Solartron 1255 frequency response analyzer in combination with a measurement resistor, at frequencies from 0.1 to $10 \mathrm{kHz}$ with

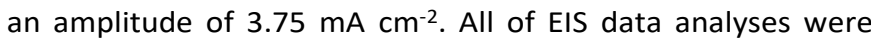
carried out using the Python-based software Ravdav. ${ }^{32}$

The surface exchange kinetics of bare and catalyst-coated LSF were evaluated by electrical conductivity relaxation (ECR) measurement. Dense LSF bars were prepared by pressing, sintering, and polishing, as described in previous work. ${ }^{33}$ Surface coated LSF bars were prepared by a similar infiltration procedure as described above for three cells. The electrical conductivity was measured by the four-probe technique. The samples were heated to $750{ }^{\circ} \mathrm{C}$ with heating rate of $2{ }^{\circ} \mathrm{C} \mathrm{min}-1$ and held for $4 \mathrm{~h}$ to calcine the coating. All the measurements were performed by changing $\mathrm{pO}_{2}$ from 0.2 to 0.1 bar (reduction runs) and from 0.1 to 0.2 bar (oxidation runs). A detailed description of ECR measurement and data fitting can be found in our previous work. ${ }^{33}$

\section{Results and discussion}

\subsection{Microstructure of LSF electrodes}

The shapes and exposed facets of the CGO nanocrystals were examined using TEM. Fig. 1a shows that CGO nanocrystals have well - defined octahedral shapes with sizes between 25-45 nm and mainly expose (111) facets with the lattice fringes at 0.31 $n m .{ }^{26,34}$ Shown in Fig. $1 \mathrm{~b}$ is a typical SEM image of the bare LSF electrode backbone after firing at $1100^{\circ} \mathrm{C}$ for $5 \mathrm{~h}$, showing smooth surfaces and clear grains. In Fig. 1c-e, images of CGO, $\mathrm{Pr}_{6} \mathrm{O}_{11}$, and the hybrid-catalyst $\left(\mathrm{CGO}+\mathrm{Pr}_{6} \mathrm{O}_{11}\right)$-coated LSF electrodes after calcining at $750^{\circ} \mathrm{C}$ for $4 \mathrm{~h}$ are displayed. Fig. $1 \mathrm{c}$ shows that CGO nanocrystals are uniformly deposited on the LSF grains and that they have maintained their shapes. Once coated with the $\operatorname{Pr}_{6} \mathrm{O}_{11}$ catalyst, a continuous and seemingly dense film is observed on the surface of the LSF grains, appearing rougher (Fig. 1d). Fig. 1e shows that the hybrid catalyst covers the LSF very well with particle size of 25-60 nm and forms a nanoporous coating. Compared to the dense $\operatorname{Pr}_{6} \mathrm{O}_{11}$ coating obtained after $\operatorname{Pr}\left(\mathrm{NO}_{3}\right)_{3}$ infiltration, this nanoporous hybrid catalyst coating achieved by co-infiltration of colloidal CGO nanocrystals and $\operatorname{Pr}\left(\mathrm{NO}_{3}\right)_{3}$ may largely enhance the available surface area for the catalytic reaction. This was demonstrated by the Brunauer - Emmett - Teller (BET) results, where surface areas for the bare LSF, CGO-coated LSF, $\mathrm{Pr}_{6} \mathrm{O}_{11}$ coated LSF, and hybrid-catalyst-coated LSF electrodes were found to be $1.2,2.9,2.1$ and $3.0 \mathrm{~m}^{2} \mathrm{~g}^{-1}$, respectively. Introducing CGO nanocrystals may decrease the amount of praseodymium used which will reduce overall cost. Formation of the targeted CGO, $\operatorname{Pr}_{6} \mathrm{O}_{11}$ and $\mathrm{CGO}+\mathrm{Pr}_{6} \mathrm{O}_{11}$ composite in the coatings is confirmed by the XRD patterns of powders, synthesized by calcinating the infiltrate solution at $750^{\circ} \mathrm{C}$ (Fig. 1f). The phase reaction between LSF and as-coated CGO and $\mathrm{Pr}_{6} \mathrm{O}_{11}$ is considered negligible, based on our recent work and the previously reported results. ${ }^{21,35}$

\subsection{Performance and durability of the LSF electrodes}


The electrochemical performance of the bare LSF, CGO-coated LSF, $\operatorname{Pr}_{6} \mathrm{O}_{11}$-coated LSF, and hybrid-catalyst-coated LSF electrodes was evaluated in symmetrical cells with a configuration of electrode/electrolyte/electrode. Fig. $2 a$ and $2 b$ compares Nyquist plots of the EIS data for the four types of electrodes obtained at 750 and $650{ }^{\circ} \mathrm{C}$, respectively. All of the coated LSF electrodes show significantly reduced polarization resistances $\left(R_{p}\right)$ when compared to the bare LSF. The hybridcatalyst-coated LSF electrode displays the lowest $R_{p}$ among the four. For instance, the $R_{p}$ value of the hybrid-catalyst-coated LSF at $750{ }^{\circ} \mathrm{C}$ is $0.017 \Omega \mathrm{cm}^{2}$, about one order of magnitude lower than that of the bare LSF $\left(0.197 \Omega \mathrm{cm}^{2}\right), \sim 80 \%$ lower than that of CGO-coated LSF $\left(0.089 \Omega \mathrm{cm}^{2}\right)$, and $\sim 40 \%$ lower than that of $\operatorname{Pr}_{6} \mathrm{O}_{11}$-coated LSF $\left(0.028 \Omega \mathrm{cm}^{2}\right)$ under the same conditions.

The here prepared hybrid-catalyst-coated LSF electrode is among the fastest ones reported on cobalt-free materials. ${ }^{18,} 36$ Even though it is LSF based and cobalt-free, its performance matches those of the high-performance cobalt-containing electrodes reported recently, including LSCF or LSCF nanofiber ${ }^{9}$, BSCF-CGO10 mixture or nanofibers ${ }^{12}, \mathrm{SrTi}_{0.3} \mathrm{Fe}_{0.63} \mathrm{Co}_{0.07} \mathrm{O}_{3-\delta}$ $(\mathrm{STFC}-07)^{37}$ and $\mathrm{PBCC}^{14}$ as well as several representative surface-coated-electrodes such as $\mathrm{PrSrCoMnO}_{6-\delta}$ (PSCM)coated $\mathrm{LSCF}^{38}$, multi-phase catalysts (composed of $\mathrm{BaCoO}_{3-\mathrm{x}}$ (BCO) and $\mathrm{PrCoO}_{3-\mathrm{x}}$ (PCO) nanoparticles and a conformal PBCC thin film)-coated $\mathrm{LSCF}^{39}$, SSC-coated LSCF/CGO10 ${ }^{40}$, $\mathrm{PrNi}_{0.5} \mathrm{Mn}_{0.5} \mathrm{O}_{3}$ (PNM) thin film and $\mathrm{PrO}_{\mathrm{x}}$ nanoparticles-coated $\mathrm{LSCF}^{21}$, and cobaltite-coated PBCC ${ }^{41}$ (Fig. 2c). Even faster Pr- backbone $\left(R_{p} \text { of } 0.028 \Omega \mathrm{cm}^{2} \text { at } 600{ }^{\circ} \mathrm{C}\right)^{24}$ and $\mathrm{LaNi}_{0.6} \mathrm{Fe}_{0.4} \mathrm{O}_{3-\delta}$ (LNF)/CGO10 composite backbone $\left(R_{p}\right.$ of $0.074 \Omega \mathrm{cm}^{2}$ at 600 $\left.{ }^{\circ} \mathrm{C}\right)^{35}$, but they were prepared with much higher Pr-oxide loadings of $\sim 30 \mathrm{wt} . \%$ relative to the backbones and lower calcination temperatures of $600{ }^{\circ} \mathrm{C}$. The higher loading and lower calcination temperature can indeed benefit the electrode performance, but the higher loading also means higher costs and the lower calcination temperature such as $600{ }^{\circ} \mathrm{C}$ aforementioned may render the electrodes susceptible to degradation by coarsening if stack initiation or operation takes place at higher temperature. It may be possible to improve the performance of the hybrid-catalyst-coated LSF electrodes further by, for example, using CGO nanocrystals with smaller sizes or optimizing the component ratio or loading of the hybrid catalyst. Such studies will be part of our future work.

The kinetics of the electrochemical processes on these LSF electrodes were investigated by examining the distribution of relaxation time (DRT) of the EIS data. DRT analysis is a useful tool for deconvoluting the complex EIS data to separate the contributions of some key steps from the total $R_{p}$ of the electrode reaction. ${ }^{42,} 43$ In general, each peak in the DRT plot represents an electrode process, and its integral area corresponds to the resistance contribution of that process. The higher the characteristic frequency of the peak, the faster the relaxation of the corresponding process. Shown in Fig. $2 \mathrm{~d}$ is the comparison of DRT plots for symmetrical cells with the four
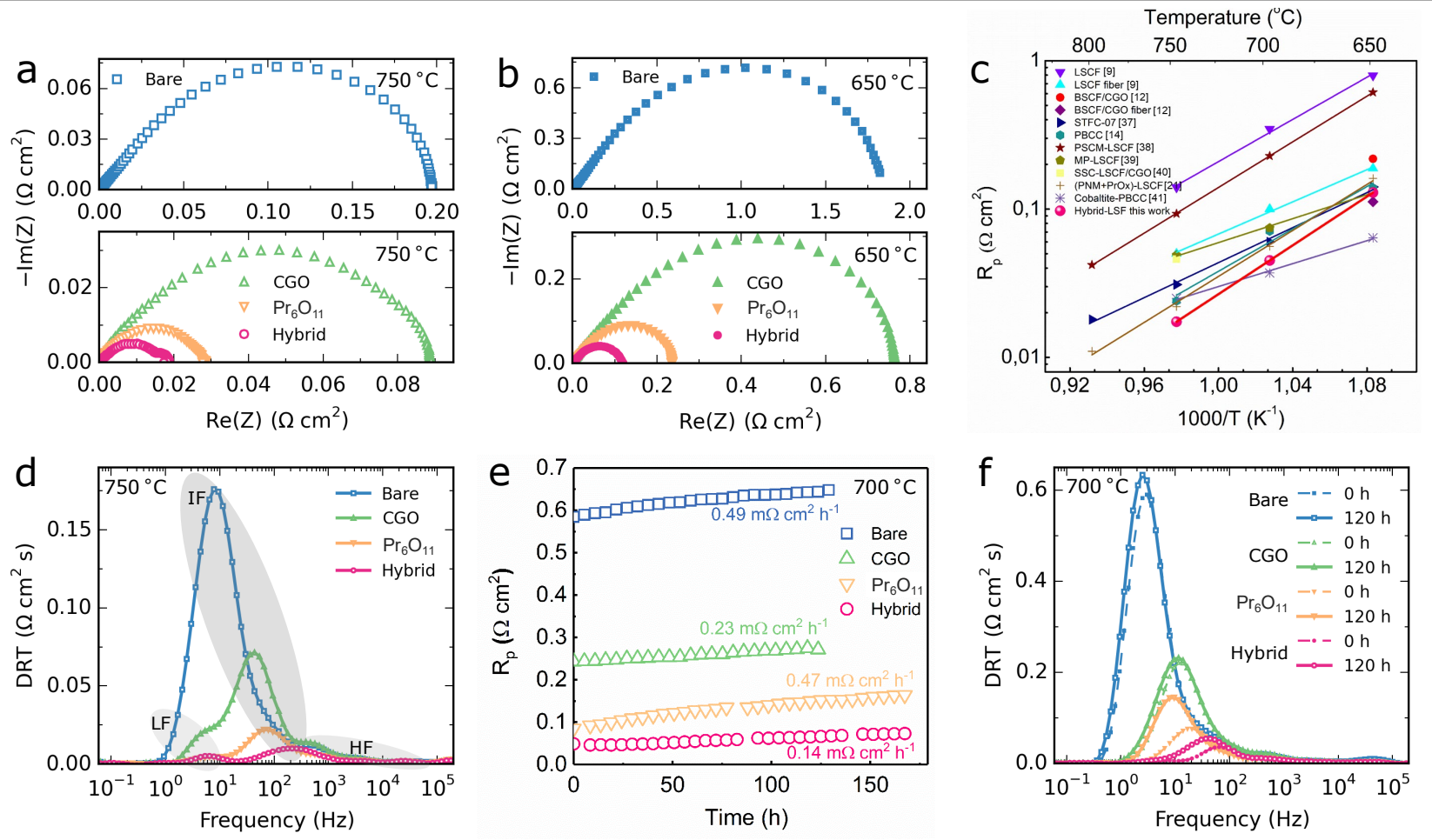

Fig. 2 Electrochemical performance and durability of symmetrical cells with four types of LSF electrodes measured under OCV conditions. Nyquist plots of EIS data measured at (a) $750{ }^{\circ} \mathrm{C}$ and (b) $650{ }^{\circ} \mathrm{C}$. (c) Comparison of $\mathrm{R}_{\mathrm{p}}$ of hybrid-catalyst-coated LSF electrode with some high-performance cobalt-containing electrodes reported recently. (d) DRT plots of EIS data for four types of LSF electrodes measured at $750{ }^{\circ} \mathrm{C}$. (e) Durability on symmetrical cells with four types of LSF electrodes at $700{ }^{\circ} \mathrm{C}$ under OCV condition. (f) DRT plots at $0 \mathrm{~h}$ and $120 \mathrm{~h}$.

oxide-coated electrodes have been reported on CGO10 
types of LSF electrodes. Fig. S1 contains Nyquist and DRT plots of bare LSF electrode under different oxygen partial pressures $\left(\mathrm{pO}_{2}\right)$ and of the hybrid-catalyst-coated electrode at different temperatures. In these DRT plots three distinct peaks are identified in the frequency range of $0.3-100 \mathrm{kHz}$, they are denoted as low frequency (LF), intermediate frequency (IF), and high frequency (HF). The LF peak has little dependence on temperature while the other peaks are characterized by a pronounced thermal activation (Fig. S1b). This strongly indicates that the LF peak is related to gas diffusion within the pores of the electrodes since gas diffusion is only mildly temperature dependent. ${ }^{39}$ The IF peak has a strong dependence on temperature and $\mathrm{pO}_{2}$ (Fig. S1b and S1d), indicating that the IF peak is associated with the oxygen surface exchange processes including oxygen adsorption/desorption, dissociation, and/or surface diffusion. ${ }^{14}, 39$ The insensitivity of the $\mathrm{HF}$ peak to $\mathrm{pO}_{2}$ (Fig. S1d) suggests that the HF peak is likely related to transport of $\mathrm{O}^{2-}$ within the LSF backbone and/or across the electrode/electrolyte interface, which are processes less dependent on $\mathrm{pO}_{2} .{ }^{14,} 39$ It is clearly seen in Fig. $2 \mathrm{~d}$ that at $750{ }^{\circ} \mathrm{C}$ the resistance of the IF peak (surface exchange processes) dominates the total $R_{p}$ of the bare LSF electrode, and that this peak decreases significantly by introducing coatings on the electrode. Also, its characteristic frequency shifts to higher values. The hybrid-catalyst-coated electrode has the highest characteristic frequency and the lowest resistance of the IF peak. These results are consistent with results of characterizations of the surface exchange coefficient (k) from

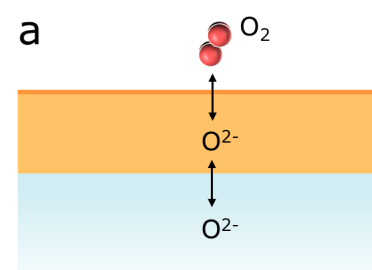

LSF
$\mathrm{Pr}_{6} \mathrm{O}_{11}$

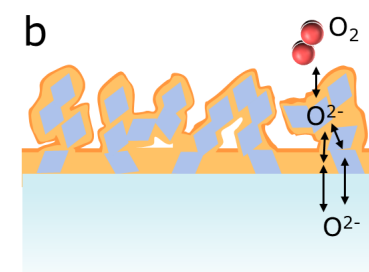

CGO

Active surface
Fig. 3 Schematics of (a) the $\operatorname{Pr}_{6} \mathrm{O}_{11}$-coated LSF electrode, and (b) the hybrid-catalyst-coated LSF electrode.

ECR measurements. The $k$ value of a bar of LSF is significantly increased after coating with catalysts, and the hybrid catalyst coated LSF possesses the highest $\mathrm{k}$ value (Fig. S2). For example, the $\mathrm{k}$ values at $750^{\circ} \mathrm{C}$ are $2.07 \times 10^{-4}, 9.71 \times 10^{-4}, 1.67 \times 10^{-3} \mathrm{~cm}$ $\mathrm{s}^{-1}$ for the bare LSF, $\mathrm{Pr}_{6} \mathrm{O}_{11}$-coated LSF, and the hybrid-catalystcoated LSF, respectively. The hybrid-catalyst-coated LSF electrode shows the highest $k$ in ECR and lowest $R_{p}$ in the symmetrical cell due most likely to its unique nanostructure, which combines the effects of high intrinsic activity of $\operatorname{Pr}_{6} \mathrm{O}_{11}$ and the large surface area enabled by the CGO nanocrystals, as shown in Fig. 3.

The short-term durability of the four types of LSF electrodes was investigated using symmetrical cells aged at $700{ }^{\circ} \mathrm{C}$. The evolution of $\mathrm{R}_{\mathrm{p}}$ with time is summarized in Fig. 2e. The order in degradation rate is: bare LSF $\left(0.49 \mathrm{~m} \Omega \mathrm{cm}^{2} \mathrm{~h}^{-1}\right)>\operatorname{Pr}_{6} \mathrm{O}_{11}-\mathrm{LSF}$
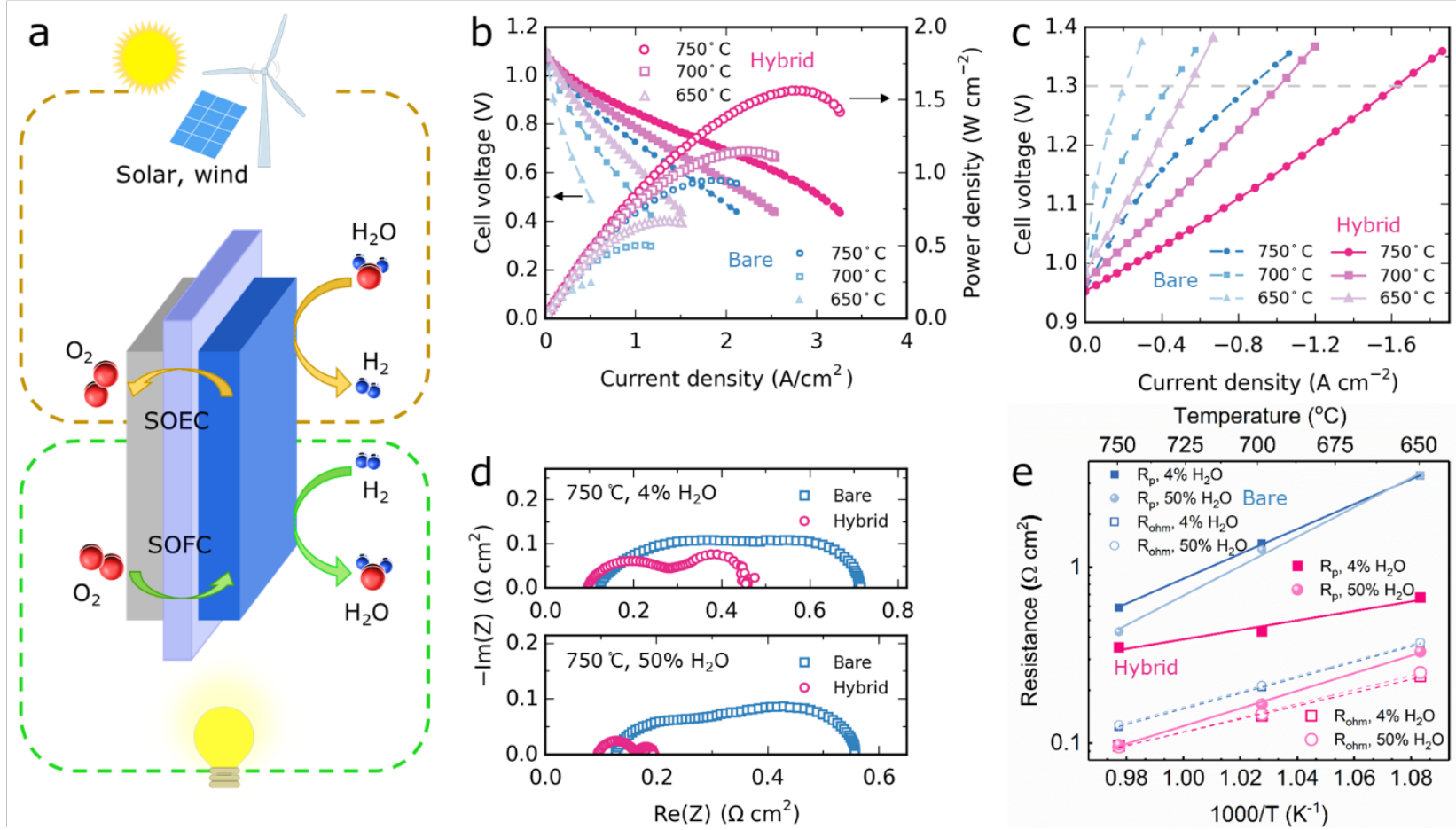

Fig. 4 (a) Schematic of the operation of solid oxide cells. Electrochemical performance on Ni/YSZ fuel-electrode-supported cells with the bare LSF and hybrid modified LSF oxygen electrodes. (a) Voltage and power density versus current density (I-V-P) measured at $650-750^{\circ} \mathrm{C}$ (fuel-cell mode). (b) Voltage versus current density (I-V) measured at $650-750{ }^{\circ} \mathrm{C}$ (electrolysis mode). (c) Nyquist plots of EIS data recorded at $750{ }^{\circ} \mathrm{C}$ under OCV. (d) Comparison of $R_{\mathrm{ohm}}$ and $\mathrm{R}_{\mathrm{p}}$ under OCV. 
$\left(0.14 \mathrm{~m} \Omega \mathrm{cm}^{2} \mathrm{~h}^{-1}\right)$. Fig. $2 \mathrm{f}$ shows a comparison of DRT plots at 0 $\mathrm{h}$ and $120 \mathrm{~h}$ for the four types of symmetrical cells. After $120 \mathrm{~h}$ of tests, all of the DRT plots display a shift in characteristic frequency to lower frequency on the IF peak and an accompanying increase of the corresponding integral resistance, reflecting a reduced rate of the surface exchange process on the electrodes. Remarkably, the CGO-coated LSF and hybrid-catalyst-coated LSF electrodes show a significantly smaller increase in the IF peak resistance in comparison with that of $\mathrm{Pr}_{6} \mathrm{O}_{11}$-coated LSF, revealing a positive effect on electrode durability of introducing CGO nanocrystals into the coating.

\subsection{Performance and durability of full cells incorporating the hybrid-catalyst-coated LSF oxygen electrodes}

To evaluate the performance of the hybrid-catalyst-coated LSF oxygen electrode in an actual full cell, fuel-electrode-supported cells with a configuration of $\mathrm{Ni} / \mathrm{YSZ}$ support | Ni/YSZ fuel electrode | YSZ electrolyte | CGO10 barrier | hybrid-catalystcoated LSF oxygen electrode were fabricated and tested under both fuel-cell and electrolysis operating conditions (Fig. 4a). A cross-sectional view of the cell components is shown in Fig. S3. Fig. $4 \mathrm{~b}$ shows the typical I-V-P curves of the cell tested under representative fuel cell conditions with $4 \% \mathrm{H}_{2} \mathrm{O}-96 \% \mathrm{H}_{2}$ fed to the fuel electrode and dry air to the oxygen electrode. For comparison, the performance of a cell with a bare LSF electrode (LSF cell) was also characterized under identical test conditions. The hybrid-catalyst-coated LSF cell delivers peak power densities (PPDs) of 1.57, 1.15, $0.67 \mathrm{~W} \mathrm{~cm}^{-2}$ at 750, 700, and 650 ${ }^{\circ} \mathrm{C}$, respectively, about 70,130 , and $170 \%$ higher than those of the LSF cell $\left(0.94,0.50,0.25 \mathrm{~W} \mathrm{~cm}^{-2}\right.$ at 750,700 , and $650{ }^{\circ} \mathrm{C}$, respectively).

Fig. 4c shows the I-V curves of the cells tested under electrolysis conditions with $50 \% \mathrm{H}_{2} \mathrm{O}-50 \% \mathrm{H}_{2}$ fed to the fuel electrode and dry air to the oxygen electrode. At the preferred electrolysis operation voltage of $1.3 \mathrm{~V}$, the current densities of the hybrid-catalyst-coated LSF cell are 1.62, 1.01, $0.54 \mathrm{~A} \mathrm{~cm}^{-2}$ at 750,700 , and $650{ }^{\circ} \mathrm{C}$, respectively; these values are about 90 , 130 , and $170 \%$ higher than those of the LSF cell $(0.86,0.44,0.20$ A cm${ }^{-2}$ at 750,700 , and $650{ }^{\circ} \mathrm{C}$, respectively). In light of the results on symmetrical cells, this significantly improved performance observed on the hybrid-catalyst-coated LSF cell under realistic fuel cell and electrolysis operating conditions is as expected. The results demonstrate that surface modification by the suggested nano-engineered hybrid catalyst coating can be effectively transferred to real cell architecture resulting in well performing cells. Encouragingly, the behavior of the hybridcatalyst-coated LSF cell reported here competes well with those of high-performance SOCs based on cobalt-containing electrodes. ${ }^{14,}$ 21, 38, 41,44

Fig. 4d shows typical EIS data of the hybrid-catalyst-coated LSF cell and the LSF cell acquired at $750{ }^{\circ} \mathrm{C}$ under OCV conditions. The polarization resistance $\left(R_{p}\right)$ is significantly reduced by the hybrid-catalyst coating. For example, the $R_{p}$ of the hybrid-catalyst-coated LSF cell is $0.098 \Omega \mathrm{cm}^{2}$ under $50 \% \mathrm{H}_{2} \mathrm{O}-50 \% \mathrm{H}_{2}$ fed to the fuel electrode, which is only $23 \%$ of that of the LSF cell $\left(0.429 \Omega \mathrm{cm}^{2}\right)$ under identical test conditions. Moreover, the hybrid-catalyst-coated LSF cell shows lower activation energy of $R_{p}$ compared with the LSF cell (Fig. 4e), consistent with the more significant improvement in performance at low temperature observed from the I-V curves in Fig. $4 \mathrm{a}$ and $4 \mathrm{~b}$. Besides, a moderate reduction in the ohmic resistance $\left(R_{\mathrm{ohm}}\right)$ was observed after the hybrid-catalyst coating. This could be attributed to the infiltration of $\operatorname{Pr}_{6} \mathrm{O}_{11}$ into the porous CGO10 barrier layer (Fig. S4) enabling increased electrical conductivity and also the improved electrical contact at the barrier layer-electrode interface. ${ }^{40}$

Durability is one of the key factors determining the practical application of SOCs. The long-term durability of the hybridcatalyst-coated LSF cell was evaluated at $650^{\circ} \mathrm{C}$ in both fuel-cell and electrolysis modes, as shown in Fig. 5 . When operated in fuel-cell mode under a constant current density of $0.5 \mathrm{~A} \mathrm{~cm}^{-2}$, the cell experiences an initial degradation followed by an activation during the first $300 \mathrm{~h}$ (Fig. 5a). Subsequently, it displays excellent durability in the following 800 h. EIS data obtained during the durability test shows that it is the $R_{p}$ that dictates the evolution of total resistance (Fig. $5 b$ ). $R_{p}$ first increases and then decreases over the first $300 \mathrm{~h}$, and stabilizes afterwards. $R_{\text {ohm }}$ is practically unaltered over the test period.

When operated for steam electrolysis under a constant current density of $-0.5 \mathrm{~A} \mathrm{~cm}^{-2}$, however, the hybrid-catalystcoated LSF cell shows a considerable degradation. The cell voltage increases from 1.260 to $1.491 \mathrm{~V}$ in a test period of 500 $\mathrm{h}$, with an accelerating degradation from $200 \mathrm{~h}$ (Fig. 5c). A similar accelerated degradation phenomenon has been observed in our previous work, where the cell degraded at rates of $0.066 \mathrm{~V} \mathrm{kh}^{-1}$ in the first $500 \mathrm{~h}$ and $0.162 \mathrm{~V} \mathrm{kh}^{-1}$ in the following 500 h. ${ }^{45}$ The EIS data shows that the $R_{\text {ohm }}$ is stable during the continuous electrolysis operation (Fig. $5 \mathrm{~d}$ and $5 \mathrm{e}$ ), whereas an increase in $R_{p}$ from 0.387 to $0.741 \Omega \mathrm{cm}^{2}$ is observed.

In order to clarify the contributions of each electrode to the increase in $\mathrm{R}_{\mathrm{p}}$, the EIS data shown in Fig. 5e were analyzed using DRT. The results are shown in Fig. $5 f$. Fig. S5 presents the EIS data of the cell measured under different temperatures and gas conditions and corresponding DRT results. In all DRT plots four distinct peaks are identified, denoted P1 to P4 from high to low frequency, corresponding to at least four electrode processes. It is shown in Fig. S5b that the processes associated with P1, P2, and $\mathrm{P} 3$ are characterized by a pronounced thermal activation while P4 is not sensitive to temperature. Fig. S5d shows that P2 and $\mathrm{P} 4$ are very sensitive to the ratio of $\mathrm{H}_{2} \mathrm{O}$ to $\mathrm{H}_{2}$ in the fuel electrode while $\mathrm{P} 1$ and $\mathrm{P} 3$ are almost independent of that. On the basis of these results and previously reported analyses:46-48 $\mathrm{P} 1$ is likely related to the transport of oxygen anions through the ionic conducting networks in the electrodes, and the major contribution of $\mathrm{P} 1$ likely originates from the YSZ network of the fuel electrode; P2 is associated with the hydrogen evolution reaction (HER) at the triple-phase boundaries (TPBs) of the fuelelectrode; P3 is likely related to the OER at the active sites of the oxygen electrode and P4 represents the gas diffusion and conversion. Fig. $5 f$ shows that among four peaks the integral resistance of $P 2$ dominates the total $R_{p}$ initially $(0 h)$ and has the 

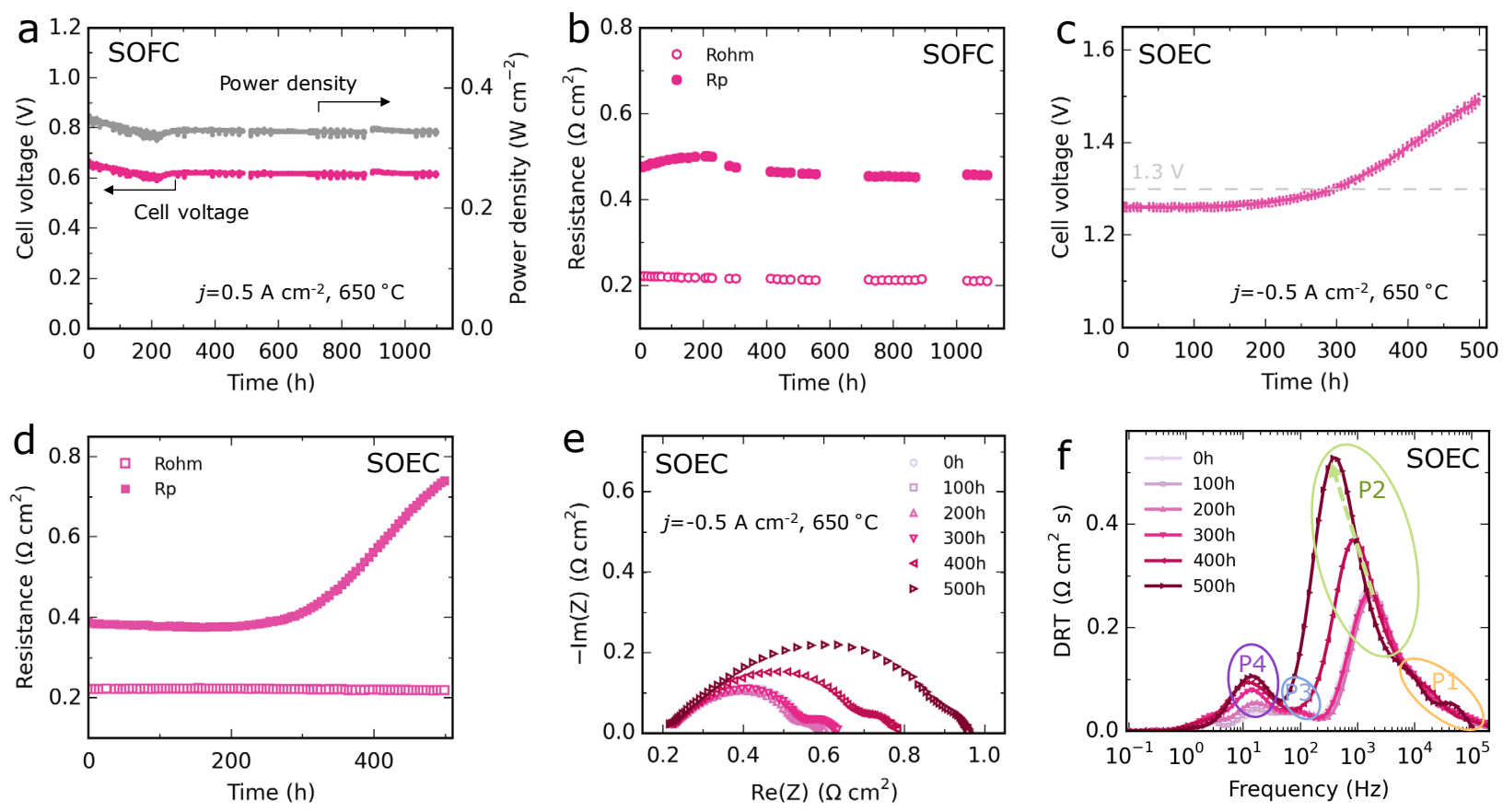

Fig. 5 Durability on Ni/YSZ fuel-electrode-supported cells with the hybrid modified LSF oxygen electrode. Fuel-cell operation under a constant current density of $0.5 \mathrm{~A} \mathrm{~cm}^{-2}$ at $650{ }^{\circ} \mathrm{C}$ with $4 \% \mathrm{H}_{2} \mathrm{O}-96 \% \mathrm{H}_{2}$ fed to the fuel electrode and dry air to the oxygen electrode. (a) Evolution of cell voltage and power density. (b) Evolution of $\mathrm{R}_{\mathrm{ohm}}$ and $\mathrm{R}_{\mathrm{p}}$. Electrolysis operation under a constant current density of $-0.5 \mathrm{~A} \mathrm{~cm}^{-2}$ at $650{ }^{\circ} \mathrm{C}$ with $50 \% \mathrm{H}_{2} \mathrm{O}-50 \% \mathrm{H}_{2}$ fed to the fuel electrode and dry air to the oxygen electrode. (c) Evolution of cell voltage. (d) Evolution of $R_{\text {ohm }}$ and $R_{p}$. (e) Nyquist plots and (f) DRT plots of EIS data recorded during electrolysis operation. The periodic fluctuation of cell voltage in Fig. $5 \mathrm{a}$ and $5 \mathrm{c}$ is due to recording EIS data.

largest increase over $500 \mathrm{~h}$ of operation. The increase in P2 is also accelerated from $200 \mathrm{~h}$, corresponding well to the trend observed in Fig. 5c. This trend likely depends on the progress of microstructural evolution at the $\mathrm{Ni} / \mathrm{YSZ}$ electrode, which is driven by the cell overpotential. The accelerated degradation is probably due to the fact that the accumulated microstructural damage and increased overpotential lead to additional and even worse microstructural damages, such as reduction of YSZ observable only at high overpotential. ${ }^{49}$ Further experiments are needed in order to clarify the different stages of degradation and the mechanisms behind. Noteworthy, the resistance of $\mathrm{P} 3$ is much smaller than that of $\mathrm{P} 2$ and remains relatively constant. These results suggest that the hybridcatalyst-coated LSF oxygen electrode has good activity and durability for the OER when operated under these conditions, and among the two electrodes of the present cell, the Ni/YSZ fuel electrode is the one limiting cell performance and durability.

\subsection{Performance and durability of double-side modified cell}

The observed degradation of the Ni/YSZ fuel electrode during electrolysis operation is not surprising and has been reported previously. ${ }^{49-52} \mathrm{~A} \mathrm{Ni} / \mathrm{YSZ}$ electrode is degraded much faster in electrolysis mode than in fuel cell mode when operated at the same current density. ${ }^{53}$ Recently, encouraging progress has been made in understanding the degradation mechanism and in strategies to reduce degradation. ${ }^{29,45,46,54,55}$ We have found that surface modification of the $\mathrm{Ni} / \mathrm{YSZ}$ electrode by coating nano-sized $\mathrm{Ce}_{0.8} \mathrm{Gd}_{0.2} \mathrm{O}_{2-\delta}$ (CGO20) electrocatalysts is an effective approach to enhance the cell durability. ${ }^{29,} 45,56$ Here, we applied this approach to the hybrid-catalyst-coated LSF cell thus resulting in a double-side modified cell (with a CGO2Ocoated Ni/YSZ fuel electrode and the hybrid-catalyst-coated LSF oxygen electrode). At $1.3 \mathrm{~V}$, the current densities of the such cell are 1.86, 1.41, $0.82 \mathrm{~A} \mathrm{~cm}^{-2}$ at 750,700 , and $650^{\circ} \mathrm{C}$, respectively (Fig. 6a). These values are higher than those of the hybrid-catalyst-coated LSF cell under identical conditions (Fig. 4c), indicating (as expected) an improvement in cell performance by introducing CGO2O coating into the Ni/YSZ electrode. Fig. $6 \mathrm{~b}$ shows the EIS data of the double-side modified cell at different temperatures. The corresponding $R_{p}$ and $R_{\text {ohm }}$ values are summarized in Fig. $S 6$. It is worth noting that in this temperature range the $R_{\text {ohm }}$ is higher than $R_{p}$ and constitutes more than $50 \%$ of the total resistance. Accordingly, future efforts in improving cell performance should be devoted to reducing the $\mathrm{R}_{\mathrm{ohm}}$.

More importantly, the double-side modified cell shows a significantly enhanced long-term durability under an electrolysis current density of $0.5 \mathrm{~A} \mathrm{~cm}^{-2}$ at $650{ }^{\circ} \mathrm{C}$ (Fig. $6 \mathrm{c}$ and $5 d)$. After some degradation over the first $250 \mathrm{~h}$, the degradation rate of the cell decreases continuously in the subsequent period. After $1400 \mathrm{~h}$ operation, the cell reached a voltage of $1.306 \mathrm{~V}$ (compared to $1.491 \mathrm{~V}$ after $500 \mathrm{~h}$ for the hybrid-catalyst-coated LSF cell) and a degradation rate of $\sim 0.009 \mathrm{~V} \mathrm{kh}^{-1}\left(\sim 0.69 \% \mathrm{kh}^{-1}\right)$. The EIS results shown in Fig. $6 \mathrm{~d}$ reveals that $R_{o h m}$ is almost constant over the entire test period and the increase of $R_{p}$ is slowing down gradually, showing an 

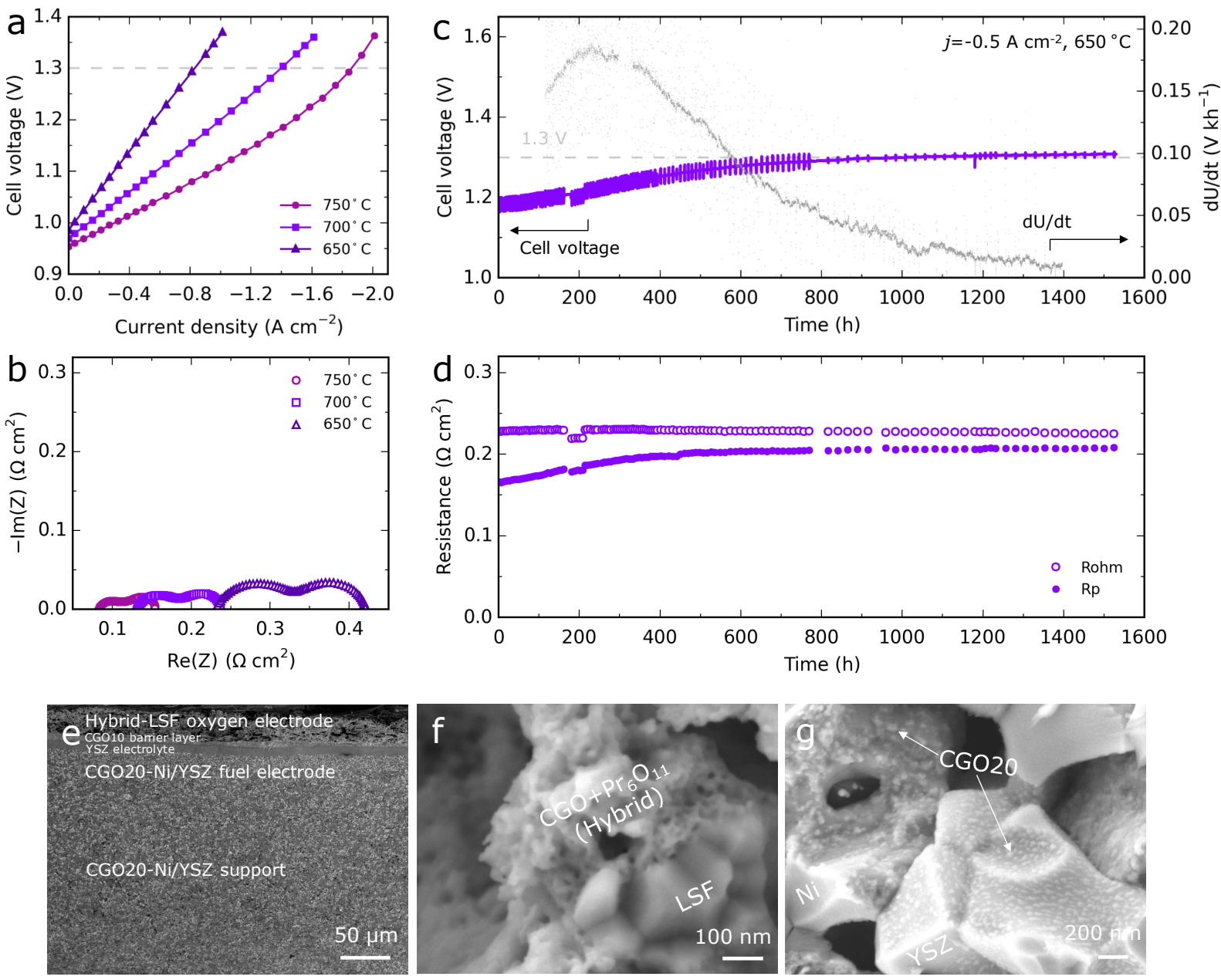

Fig. 6 Electrochemical performance and durability for electrolysis operation on the double-side modified cell measured with $50 \% \mathrm{H}_{2} \mathrm{O}-50 \% \mathrm{H}_{2}$ fed to the fuel electrode and dry air to the oxygen electrode. (a) I-V curves and (b) Nyquist plots of EIS data measured at $650-750{ }^{\circ} \mathrm{C}$. Evolution of (c) cell voltage and (d) $R_{\mathrm{ohm}}$ and $R_{\mathrm{p}}$ during the durability test. Note that the EIS data in Fig. $6 \mathrm{~b}$ was recorded under OCV condition, while the data in Fig. $6 \mathrm{~d}$ was recorded under a current density of $-0.5 \mathrm{~A} \mathrm{~cm}^{-2}$. SEM characterization of the double-side modified cell after the durability test. (e) Full cell. (f) Hybrid-catalyst-coated LSF oxygen electrode. (g) CGO20-coated Ni/YSZ fuel electrode.

increase in $R_{p}$ of less than $0.001 \Omega \mathrm{cm}^{2}$ for the last $500 \mathrm{~h}$. Fig. $6 \mathrm{e}-$ $\mathrm{g}$ shows SEM images of the double-side modified cell after the durability test. No obvious growth of nanoparticles of hybrid catalyst in the oxygen electrode is observed compared with that of the initial structure shown in Fig. 1e. Hence, the study shows that it seems feasible to achieve stable long-term operation of SOEC prepared without cobalt at high efficiency (thermoneutral conditions) with a $\mathrm{H}_{2}$ production rate of $3.48 \mathrm{ml} \mathrm{min}^{-1} \mathrm{~cm}^{-2}$ at a temperature enabling use cheap steels. ${ }^{57}$ This is important for reducing overall cost of the unit and for competing favorably with alkaline electrolysis cells, which may be operated at the same area-specific production capacity but typically at a somewhat lower electrical efficiency. ${ }^{58}$

\section{Conclusions}

In summary, the activity of an LSF-based oxygen electrode for both the ORR and the OER has been strongly enhanced by applying a nanoporous hybrid catalyst coating composed of nanoparticles of $\mathrm{CGO}$ and $\mathrm{Pr}_{6} \mathrm{O}_{11}$. The coating was realized using infiltration with a solution of colloidal CGO nanocrystals and $\operatorname{Pr}\left(\mathrm{NO}_{3}\right)_{3}$. The hybrid-catalyst-coated LSF oxygen electrode exhibited a polarization resistance as low as $0.017 \Omega \mathrm{cm}^{2}$ at 750 ${ }^{\circ} \mathrm{C}$, about one order of magnitude lower than that of bare LSF $\left(0.197 \Omega \mathrm{cm}^{2}\right)$. Furthermore, the activity of the hybrid-catalystcoated LSF electrode for both the ORR and the OER was investigated in fuel-electrode-supported cells under practical operating conditions. Excellent performance and durability were observed. The analyses of SEM, BET, ECR as well as EIS indicated that the $\mathrm{Pr}_{6} \mathrm{O}_{11}$ greatly accelerates the oxygen surface exchange kinetics and the nanoporous architecture of the catalyst coating significantly increases the surface area for the oxygen incorporation reaction, thus enabling the superior activity and durability. This work shows that well performing cobalt-free oxygen electrode can be prepared and that when applied on a CGO2O-coated $\mathrm{Ni} / \mathrm{YSZ}$ electrode supported cell stable operation at $650{ }^{\circ} \mathrm{C}$ under $-0.5 \mathrm{~A} \mathrm{~cm}^{-2}$ with cell voltage close to $1.3 \mathrm{~V}$ can be achieved. 


\section{Conflicts of interest}

There are no conflicts to declare.

\section{Acknowledgements}

This work was financially supported by the project "Efficient Power2Gas Combining SOEC and Biomass Gasification" (EUDP no. 64017-0011) and project "Towards Solid Oxide Electrolysis Plants in 2020" (ForskEL 2015-1-12276) and the project "Synfuel" (4106-00006B). X. F. Tong thanks the financial support from the China Scholarship Council (CSC201604910912). The authors also would like to thank $\mathrm{H}$. Henriksen for help with cell testing.

\section{References}

1. T. M. Gür, Energy Environ. Sci., 2018, 11, 2696-2767.

2. S. Chu and A. Majumdar, Nature, 2012, 488, 294-303.

3. J. T. S. Irvine, D. Neagu, M. C. Verbraeken, C. Chatzichristodoulou, C. Graves and M. B. Mogensen, Nat. Energy, 2016, 1, 15014.

4. C. Graves, S. D. Ebbesen, S. H. Jensen, S. B. Simonsen and M. B. Mogensen, Nat. Mater., 2015, 14, 239-244.

5. C. Duan, R. Kee, H. Zhu, N. Sullivan, L. Zhu, L. Bian, D. Jennings and R. O'Hayre, Nat. Energy, 2019, 4, 230-240.

6. S. Choi, T. C. Davenport and S. M. Haile, Energy Environ. Sci., 2019, 12, 206-215.

7. N. Ai, N. Li, S. He, Y. Cheng, M. Saunders, K. Chen, T. Zhang and S. P. Jiang, J. Mater. Chem. A, 2017, 5, 12149-12157.

8. M. J. Lopez-Robledo, M. A. Laguna-Bercero, A. Larrea and V. M. Orera, J Power Sources, 2018, 378, 184-189.

9. Y. Chen, Y. Bu, Y. Zhang, R. Yan, D. Ding, B. Zhao, S. Yoo, D. Dang, R. Hu, C. Yang and M. Liu, Adv. Energy Mater., 2017, 7, 1601890.

10. G. M. Rupp, A. K. Opitz, A. Nenning, A. Limbeck and J. Fleig, Nat Mater, 2017, 16, 640-645.

11. Z. Shao and S. M. Haile, Nature, 2004, 431, 170-173.

12. J. G. Lee, J. H. Park and Y. G. Shul, Nat Commun, 2014, 5, 4045.

13. F. He, T. Wu, R. Peng and C. Xia, J Power Sources, 2009, 194, 263268.

14. Y. Chen, S. Yoo, Y. Choi, J. H. Kim, Y. Ding, K. Pei, R. Murphy, Y. X. Zhang, B. T. Zhao, W. L. Zhang, H. J. Chen, Y. Chen, W. Yuan, C. H. Yang and M. L. Liu, Energy Environ. Sci., 2018, 11, 2458-2466.

15. B. Koo, K. Kim, J. K. Kim, H. Kwon, J. W. Han and W. Jung, Joule, 2018, 2, 1476-1499.

16. A. U. Rehman, M. Li, R. Knibbe, M. S. Khan, V. K. Peterson, H. E. A. Brand, Z. Li, W. Zhou and Z. Zhu, ACS Appl Mater Interfaces, 2019, 11, 26909-26919.

17. Y. L. Huang, A. M. Hussain, I. A. Robinson and E. D. Wachsman, ACS Appl Mater Interfaces, 2018, 10, 28635-28643.

18. N. A. Baharuddin, A. Muchtar and M. R. Somalu, Int. J. Hydrogen Energy, 2017, 42, 9149-9155.

19. G. Yang, W. Zhou, M. Liu and Z. Shao, ACS Appl Mater Interfaces, 2016, 8, 35308-35314.

20. Y. Niu, J. Sunarso, F. Liang, W. Zhou, Z. Zhu and Z. Shao, J. Electrochem. Soc., 2011, 158, B132.

21. Y. Chen, Y. Chen, D. Ding, Y. Ding, Y. Choi, L. Zhang, S. Yoo, D. Chen, B. deGlee, H. Xu, Q. Lu, B. Zhao, G. Vardar, J. Wang, H. Bluhm, E. J. Crumlin, C. Yang, J. Liu, B. Yildiz and M. Liu, Energy Environ. Sci., 2017, 10, 964-971.
22. Y. Chen, S. Yoo, X. Li, D. Ding, K. Pei, D. Chen, Y. Ding, B. Zhao, R. Murphy, B. deGlee, J. Liu and M. Liu, Nano Energy, 2018, 47, 474480.

23. Y.-L. Huang, A. M. Hussain and E. D. Wachsman, Nano Energy, 2018, 49, 186-192.

24. C. Nicollet, A. Flura, V. Vibhu, A. Rougier, J.-M. Bassat and J.-C. Grenier, Int. J. Hydrogen Energy, 2016, 41, 15538-15544.

25. E. Dogdibegovic, R. Wang, G. Y. Lau, A. Karimaghaloo, M. H. Lee and M. C. Tucker, J Power Sources, 2019, 437, 226935.

26. Y. Xu, N. Farandos, M. Rosa, P. Zielke, V. Esposito, P. V. Hendriksen, S. H. Jensen, T. Li, G. Kelsall and R. Kiebach, International Journal of Applied Ceramic Technology, 2018, 15, 315-327.

27. X. Tong, T. Luo, X. Meng, H. Wu, J. Li, X. Liu, X. Ji, J. Wang, C. Chen and Z. Zhan, Small, 2015, 11, 5581-5588.

28. A. Hagen, M. Menon, R. Barfod, P. V. Hendriksen, S. Ramousse and P. H. Larsen, Fuel Cells, 2006, 6, 146-150.

29. X. Tong, S. Ovtar, K. Brodersen, P. V. Hendriksen and M. Chen, ACS Appl Mater Interfaces, 2019, 11, 25996-26004.

30. A. Samson, M. Sogaard, R. Knibbe and N. Bonanos, J. Electrochem. Soc., 2011, 158, B650.

31. S. D. Ebbesen, C. Graves, A. Hauch, S. H. Jensen and M. Mogensen, J. Electrochem. Soc., 2010, 157, B1419-B1429.

32. C. Graves, Ravdav, Data Analysis Software, Ver 0.97, 2012.

33. Đ. Tripković, R. Küngas, M. B. Mogensen and P. V. Hendriksen, J. Mater. Chem. A, 2019, 7, 11782-11791.

34. G. Perin, C. Gadea, M. Rosa, S. Sanna, Y. Xu, R. Kiebach, A. Glisenti and V. Esposito, J Phys Chem Solids, 2019, 132, 162-171.

35. M. Khoshkalam, M. A. Faghihi-Sani, X. Tong, M. Chen and P. V. Hendriksen, J. Electrochem. Soc., 2020, 167, 024505.

36. S. S. Hashim, F. Liang, W. Zhou and J. Sunarso, ChemElectroChem, 2019, 6, 3549-3569.

37. S.-L. Zhang, H. Wang, M. Y. Lu, A.-P. Zhang, L. V. Mogni, Q. Liu, C.X. Li, C.-J. Li and S. A. Barnett, Energy Environ. Sci., 2018, 11, 18701879.

38. D. Ding, M. Liu, Z. Liu, X. Li, K. Blinn, X. Zhu and M. Liu, Adv. Energy Mater., 2013, 3, 1149-1154.

39. Y. Chen, Y. M. Choi, S. Yoo, Y. Ding, R. Q. Yan, K. Pei, C. Qu, L. Zhang, I. Chang, B. T. Zhao, Y. X. Zhang, H. J. Chen, Y. Chen, C. H. Yang, B. deGlee, R. Murphy, J. Liu and M. L. Liu, Joule, 2018, 2, 938-949.

40. K. Joong Yoon, M. Biswas, H.-J. Kim, M. Park, J. Hong, H. Kim, J.W. Son, J.-H. Lee, B.-K. Kim and H.-W. Lee, Nano Energy, 2017, 36, 9-20.

41. Y. Chen, S. Yoo, W. Zhang, J. H. Kim, Y. Zhou, K. Pei, N. Kane, B. Zhao, R. Murphy, Y. Choi and M. Liu, Acs Catal, 2019, 9, 71377142.

42. A. Leonide, V. Sonn, A. Weber and E. Ivers-Tiffée, J. Electrochem. Soc., 2008, 155, B36.

43. V. Sonn, A. Leonide and E. Ivers-Tiffée, J. Electrochem. Soc., 2008, 155, B675.

44. X. Tong, S. Ovtar, K. Brodersen, P. V. Hendriksen and M. Chen, J Power Sources, 2020, 451, 227742.

45. S. Ovtar, X. Tong, J. J. Bentzen, K. T. S. Thyden, S. B. Simonsen and M. Chen, Nanoscale, 2019, 11, 4394-4406.

46. A. Hauch, K. Brodersen, M. Chen and M. B. Mogensen, Solid State lonics, 2016, 293, 27-36.

47. M. Chen, X. Sun, C. Chatzichristodoulou, S. Koch, P. V. Hendriksen and M. B. Mogensen, ECS Trans., 2017, 78, 3077-3088.

48. S. H. Jensen, A. Hauch, P. V. Hendriksen and M. Mogensen, J. Electrochem. Soc., 2009, 156, B757-B764.

49. M. Chen, Y. L. Liu, J. J. Bentzen, W. Zhang, X. Sun, A. Hauch, Y. Tao, J. R. Bowen and P. V. Hendriksen, J. Electrochem. Soc., 2013, 160, F883-F891. 
50. P. Hjalmarsson, X. Sun, Y.-L. Liu and M. Chen, J Power Sources, 2014, 262, 316-322.

51. D. The, S. Grieshammer, M. Schroeder, M. Martin, M. Al Daroukh, F. Tietz, J. Schefold and A. Brisse, J Power Sources, 2015, 275, 901911.

52. A. Hauch, S. D. Ebbesen, S. H. Jensen and M. Mogensen, J. Electrochem. Soc., 2008, 155, B1184.

53. M. Trini, A. Hauch, S. De Angelis, X. Tong, P. V. Hendriksen and M. Chen, J Power Sources, 2020, 450, 227599.

54. M. B. Mogensen, A. Hauch, X. Sun, M. Chen, Y. Tao, S. D. Ebbesen, K. V. Hansen and P. V. Hendriksen, Fuel Cells, 2017, DOI: 10.1002/fuce.201600222.

55. M. P. Hoerlein, M. Riegraf, R. Costa, G. Schiller and K. A. Friedrich, Electrochim. Acta, 2018, 276, 162-175.

56. X. Tong, P. V. Hendriksen, A. Hauch, X. Sun and M. Chen, J. Electrochem. Soc., 2020, 167, 024519.

57. B. Talic, V. Venkatachalam, P. V. Hendriksen and R. Kiebach, J Alloy Compd, 2019, DOI: 10.1016/j.jallcom.2019.153229, 153229.

58. S. D. Ebbesen, S. H. Jensen, A. Hauch and M. B. Mogensen, Chemical reviews, 2014, 114, 10697-10734. 